\title{
Algunas observaciones sobre la lengua de Borges
}

$\mathbf{J}^{\circ}$ ORGE Luis Borges es considerado corrientemente como escritor ultramodernista, o por lo menos de comienzos ultramodernistas. No pretendemos negar sus vínculos con el grupo de Prisma y Proa que contribuyó a fundar, pero sí destacar su personalidad lingüística que le individualiza desde un principio y le aleja de las escuelas poéticas del ultramodernismo para acercarle a los grandes renovadores literarios de todos los tiempos.

Al hablar de la lengua de Borges no hacemos distinción entre: su prosa y su verso pues en su caso particular la diferencia radica en el ritmo y en el movimiento más que en el contenido, el cual, como él mismo advierte en "Profesión de fe literaria", es autobiagráfico.1

Borges ve la lengua como único medio de que dispone el hombre para revelar y fijar su verdad humana, y así se convierte en su constante preocupación. La trabaja, la cincela. Clásico y moderno, como Mallarmé, cultiva la lengua tradicional con la cual quiere modelar una nueva, pero contrariamente al poeta francés que veía un abismo entre la palabra escrita y la emoción o la idea original, Borges siente la palabra como medio de asir y limitar la vaguedad de la emoción o de la idea, es decir, de darle realidad. Por una parte admite que la lengua es ficticia representación de la "enigmática abundancia del

I El tamaño de mi esperanza (Buenos Aires, 1926). En adelante nos referimos a este libro por la abreviatura $\mathrm{El} \mathrm{tam}$. 
mundo." Pero así y todo, la metáfora que es la lengua, esa ineludible ficción o engaño, es una experiencia humana común, y como tal es "edificadora de realidades". 2 Su papel es comunicar con exactitud la realidad, no la circunstancial sino la esencial. "Creo - dice— en la entendibilidá final de todas las cosas, y en la de la poesía por consiguiente". ${ }^{3}$ En otras palabras, su actitud literaria difiere radicalmente de buen número de excelentes escritores de la primer postguerra cuyos malabarismos verbales eran y siguen siendo un misterio para el lector.

Examinemos la lengua de Borges, empezando por la palabra y su uso.

La palabra en sí tiene un valor extraordinario para Borges. No es la variedad de palabras que posee un autor la que ameniza su estilo, sino los infinitos matices que cobra en diversas asociaciones emocionales. "Pienso - dice Borges-que las palabras hay que conquistarlas, viviéndolas, y que la aparente publicidad que el diccionario les regala es una falsía". 4 Efectivamente, una palabra tan corriente como arrabal -palabra dilecta suya - sirve para expresar nuevos conceptos: "arrabales del arte", "arrabales [del] verso", "arrabales del alma". En una prosa tersa o en un poema de gran sencillez aparecen expresiones como éstas amenizando la lectura:

en trances de idioma5

bondades de libro (EI id., pág. 128)

conductas de prosa (El id., pág. 86)

estilo alegórico-basurero (EI id., pág. 135)

una patria vieja de mi sentir (El tam., pág. 145)

Don Leopoldo se ha pasado los libros (El tam., pág. 105)

hace unos renglones (El tam., pág. 152)

el progresismo y el despuesismo (El tam., pág. 32)

la conjetural hermana mayor 6

una corazonada borrosa (Poemas, pág. 18)

2 "Palabreria para versos", ibidem, pág. 47.

3 . Ibidem, pág. 107.

* "Profesión de fe literaria", El tam., pág. 153.

5 El idioma de los argentinos (Buenos Aires, 1928), pág. 170. En adelante nos referimos a cste libro por la abreviatura $E l i d$.

6 Poemas (1922-1943) (Buenos Aires, 1943), pág. 18. En adelante abrevianos este libro así: Poemas, 
maciza realidad (Poemas, pág. 21)

Gólgotas ajenos (Poemas, pág. 16)

metáfora baldía (Poemas, pág. 23)

la inventiva fiebre (Poemas, pág. 129)

la prolijidad de lo real (Poemas, pág. 133)

El diminutivo, muy abundante en la obra borgiana, sobre todo la poética, forma parte integral de su estilo y aparece en el momento de mayor tensión emotiva, contribuyendo a crear la atmósfera de intimidad que caracteriza su obra: "los vagos campitos", el "pastito precario" del arrabal, el "manojito de pasto" de la Pampa.

Los neologismos de Borges, sean nombres, adjetivos o participios, se caracterizan por su cualidad sintética y la multiplicidad de representaciones concretas que encierran reduciendo así la longitud inicial de la idea sin desvirtuarla. Borges habla de

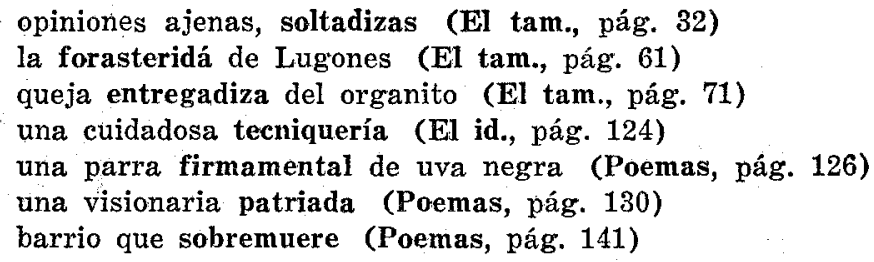

Borges no abusa del neologismo y cuando lo fabrica nos da la impresión de haber llenado una laguna en el idioma, o de que hubiera debido existir siempre. Sus neologismos no nos producen otra sorpresa que la de su acierto pues siempre están construidos sobre una base de lógicas analogías.

Como Fray Luis, Quevedo, Unamuno, Ortega y Gasset, Azorín y otros renovadores de la lengua, saca a circulación palabras que han caído en desuso y que se avienen con el clima espiritual de sus escritos:

$\begin{array}{llll}\text { lumbrerada } & \text { belísonos } & \text { jironados } & \text { altivecer } \\ \text { pobrería } & \text { dulcedumbre } & \begin{array}{l}\text { turbiedad } \\ \text { empozar }\end{array} \\ \text { nadería } & \text { plumazón } & \text { cenizal } & \text { oíble }\end{array}$

Hay algunas palabras que, según Borges, son ya en sí poéticas por "implicar destinos". Son las palabras-imagen 
apuntadas más arriba. Pero la palabra que solamente enuncia, como la usa Walt Whitman (y otros escritores de ambas Américas después de él), no le satisface. La quiere diferenciada, es decir con matiz y tono, y aquí el adjetivo juega un papel primordial: el de obligar al lector "a detenerse en el sustantivo a que se refiere". ( $E l$ tam., pág. 58). Este concepto del adjetivo no puede ser más tradicional. Podría hacerse una clasificación bastante extensa de los adjetivos de Borges según su aplicación. Más nos interesa hablar de la cualidad que Borges le pide al adjetivo: quiere un adjetivo que no obligue a un esfuerzo de figuración sino que caracterice mediatamente y abrevie conceptos: "calles enérgicas" (Poemas, pág. 11) son las del centro de Buenos Aires; en la sala vacía, anticuada y sola, conversan las "seniles butacas" (Poemas, pág. 29) ; la muerte de cada uno, a la que Rilke se refiere con su conocida frase metafísica de la propia muerte, Borges la llama "única y personal" (Poemas, pág. 13) con familiar, sencilla y tremenda inexorabilidad; la fuerza de las cosas con toda su presencia viva es la "actualidad sanguínea" (Poemas, pág. 28), palabra tal vez sugerida por el significado de la palabra inglesa sanguine (recuérdese que Borges posee a perfección el inglés como lo demuestran las composiciones en dicha lengua al final de su antología poética).

Uno de los métodos de adjetivación que emplea Borges, quizá el más original en verso y prosa, es el de seguir un proceso de semántica en sentido inverso al de la evolución anterior de la palabra, de lo abstracto a lo concreto, para llegar a una abstracción de nuevo tipo. De este modo nos presenta facetas nuevas, o sencillamente insospechadas, de realidades conocidas. Algunos ejemplos:

manos precursoras [de un ciego] -que preceden por el mismo curso (Poemas, pág. 68)

la decisiva zarpa - no sólo en la que hay decisión sino que decide del desenlace (Poemas, pág. 51)

ensalzadas minucias - a las que se da relieve o énfasis (Poemas, pág. 49)

inmortales distancias [de la Pampa] —con el doble sentido de eternas e infinitas (Poemas, pág. 11)

enaltecidas barreras (Poemas, pág. 46) 
La adjetivación de Borges es altamente metafórica como puede verse por los ejemplos que acabamos de citar. Es la imagen pues la que, en realidad, encierra el secreto de Borges.

Borges sintió la literatura como imagen al igual que los imagistas anglosajones, los ultraístas españoles y los ultramodernistas hispanoamericanos. Muchas de sus primeras poesías y prosas están hechas de imágenes ensartadas que juntas crean una atemósfera. Basta hojear algún cuento para constatar que toda la savia del pensamiento discurre por el cauce de precisas y estratégicas imágenes que lo sintetizan a la vez que lo exponen. Hasta su crítica participa de esa brevedad sintética, la cual responde al concepto temporal de nuestra época así como a la necesidad de la sacudida mental. El procedimiento metafórico al que nos referimos no es original en sí ya que los grupos arriba mencionados también lo siguieron. Lo nuevo, o por lo menos lo personal, es el motivo de la imagen, el papel que juega en el poema o en la prosa: el de comunicar mediatamente con precisión psíquica, y exigiendo un esfuerzo intelectual mínimo por parte del lector, un sentimiento o un concepto. Para ello, la imagen debe tener ciertas cualidades fácilmente asociables con la actividad humana. Más aun, debe basarse fundamentalmente en esas actividades para adquirir comunicabilidad. (Esto es aplicable al símil tanto como a la metáfora sustitutiva a la que cedió lugar después de los primeros libros). "Siempre - dice Borges- fuí novelero de metáforas; pero solicitando fuese notorio en ellas antes lo eficaz que lo insólito".7 Esta actitud de Borges establece una diferencia esencial entre él y otros ultramodernistas contemporáneos. La imagen no es pues algo que se inventa sino algo que se descubre, algo instantáneamente verdad y reconocible para todo ser humano una vez revelado. En la introducción a Poemas (1922-1943) leemos: "Si las páginas de este libro permiten algún verso feliz, perdóneme el lector la descortesía de haberlo usurpado yo, previamente". Y a modo de explicación: "Nuestras nadas poco difieren; es trivial y fortuita la circunstancia de que seas tú el lector de estos ejercicios, y yo su redactor". Ejercicios... es decir, una

7 Prólogo a Fervor de Buenos̀ Aires (Buenos Aires, 1923), pág. 3. 
costumbre intelectual mediante la cual por casualidad, y a fuerza de práctica, se descubre una pequeña verdad de eso que él llama "destino humano". Descontando la modestia del escritor y ateniéndonos al espíritu de lo escrito, entendemos mejor su amor a la lengua, su fe en ella como única base posible de verdad colectiva.

Unos comentarios más sobre la cualidad metafórica de la lengua de Borges. Primer ejemplo: "Me asestaron sofisterías..." (El tam., pág. 145). Lo maravilloso y acertado no es la asociación inesperada de asestar y sofisterías sino la - lógica y la justeza de tal asociación conceptual. Borges rehuye todo lo falso; el sofisma es algo que le produce una sacudida mental de una violencia comparable a la violencia física: de ahí el verbo asestar.

Otro ejemplo: la metáfora corriente de "clavar la mirada" le sugiere otra de la misma índole, esta vez no corriente: "desenvainado mirar" (El tam., pág. 93), en el que el participio adjetival produce una impresión visual plástica al tiempo que, habiendo evitado el lugar común, le devuelve la fuerza expresiva perdida por el uso constante.

Un tercer ejemplo: el anhelo de inmortalidad, de vencer el Tiempo, adquiere plasticidad en la metáfora: "clavar... un claro verso / de pie como una lanza sobre el tiempo" (Poemas, pág. 26), o en otra parte "versos enhiestos" (Poemas, pág. 12).

La originalidad metafórica de Borges se debe, no tanto a la profunda originalidad de su pensamiento, como a su repentino ver y sentir las cosas sin la trabazón de preconcepciones de lenguaje y expresión, o sea, fuera del lugar común. Es como si por primera vez se vieran y se pensaran las cosas y ese estreno del pensamiento se comunica al lector. En el poema titulado "Remordimiento por cualquier defunción" leemos:

\footnotetext{
Libre de la memoria, y de la esperanza, ilimitado, abstracto, casi futuro, el muerto, no es un muerto: es la muerte.
} 
El dolor por el muerto es el lugar común que utlizamos socialmente para ocultar otra verdad menos altruista: el escalofrío en presencia de la muerte.

Las metáforas de Borges no se deben exclusivamente a un esfuerzo intelectual exagerado, ni a un juego intrascendente del espíritu, como se le ha imputado alguna vez. Tampoco nos parece justificado que se hable del carácter fortuito de sus hallazgos. La palabra, el adjetivo, la imagen, forman parte de su visión del mundo y están sujetas, por decirlo así, a una especie de determinismo metafísico correspondiente a dicho mundo. Un ejemplo concreto: "El Juicio Final de cada tarde" (Poemas, pág. 27). Repetidas veces ha hablado Borges en verso y prosa del carácter inconexo de nuestros actos y pensamientos, superfice de nuestra vida, cuya única unidad aparece en la más amplia perspectiva de la repetición de todos los actos y pensamientos humanos dentro de un tiempo circular. Por otra parte, ve una identidad entre el sueño y la muerte, lo cual en sí no tiene originalidad. Pero sí la tiene el concepto que deriva de los dos conceptos expuestos aquí arriba, es decir: el resumen de cada día como entidad independiente y total, cuando se refiere a él con la frase: "Juicio Final de cada tarde".

Conclusión a estas observaciones. Tanto el verso como la prosa de Jorge Luis Borges son una sorpresa lingüústica hasta para los iniciados en lenguajes audaces, pero más aun, una sorpresa intelectual por la penetración y perspicacia con que ha sabido captar y reflejar las nuevas complejidades del pensamiento moderno. Para ello, ha hecho más elástica la lengua castellana manteniendo siempre frente a ella una actitud de respeto y reverencia. Su innovación lingüística, lejos de forzarla y desvirtuarla, como en el caso de muchos de sus contemporáneos por su esfuerzo exagerado de originalidad, consiste en sentirla y extraer de las palabras significados nuevos basándose en su etimología sin jamás hacerles violencia. "Siempre - dice - fué perseverancia de mi pluma usar de los vocablos según su primordial acepción".7 Es justamente en esta su sensibilidad verbal, y no necesariamente en la técnica, que vemos similitud con Quevedo, autor favorito suyo, al que se le ha acercado en más de una ocasión. 
Visto desde la perspectiva de un cuarto de siglo más tarde, creemos que Borges adquiere su verdadera fisonomía literaria como renovador de la lengua y que el ultramodernismo argentino que deriva de él hunde sus raíces en la tradición literaria.

Helena Percas,

Grinnell College, Iowa. 